\title{
PERANCANGAN DAN IMPLEMENTASI ALAT UKUR KUALITAS AIR MENGGUNAKAN METODE NEFELOMETRIK
}

\author{
M. Taofik Chulkamdi \\ Dosen Fakultas Teknologi Informasi, Universitas Islam Balitar, BLITAR \\ Alamat Kampus \\ chulkamdi@gmail.com
}

\begin{abstract}
Turbid warter is one of the characteristics of unclean water and unhealthy. Importance of water clarity to humans at this time then designed a device that could measure water quality using a LDR sensor, where the sensor can detect light from a diode light levels. LED penetrating the water, it will be detected water quality. Microcontroller in the system that became controlleris arduino uno. Out of this toolis the percentage rate that water quality will be displayed on the LCD. Testing water quality measuring instrument is using nefelometric. System testing is done by detecting changes in the level of water quality in five sampel of bottled water, drinking water processed two and three wastewater. The results are not clear, the higher the level of water or less clear water, the sensor output voltage is also higher.
\end{abstract}

Keywords: Arduino uno, LCD, LDR sensor, LED, Nefelometrik.

\section{Pendahuluan}

Ketersedian air yang cukup secara kualitas dan kuantitas sangat penting untuk kelangsungan hidup manusia. Dewasa ini, yang menjadi masalah utama adalah kualitas dan kuantitas air tidak mampu lagi untuk memenuhi kebutuhan yang terus meningkat. Sekitar $70 \%$ permukaan bumi ditempati oleh air, namun $97 \%$ darinya adalah air laut. Terbatasnya jumlah air bersih tidak sebanding dengan pertambahan jumlah penduduk dunia yang menyebabkan konsumsi air segar meningkat drastis. Krisis air bersih juga disebabkan oleh penurunan kualitas air sebagai akibat dari pencemaran dan kegiatan mausia. Menteri Kesehatan NO. 907/Menkes/SK/VII/2002 air yang berkualitas memiliki syarat dikonsumsi [1].

Air merupakan senyawa kimia yang sangat penting bagi kehidupan makhluk hidup di bumi ini. Fungsi air bagi kehidupan tidak dapat digantikan oleh senyawa lain. Penggunaan air yang utama dan sangat vital bagi kehidupan adalah sebagai air minum. Kehilangan air dapat menyebabkan kematian yang diakibatkan oleh dehidrasi. Bagi kehidupan manusia air diperlukan untuk bermacam-macam kegiatan dalam rumah seperti minum, mandi, mencuci dan lain sebagainya, serta air juga diperlukan dalam pertanian, industri dan perikanan [2].

\section{TinJAUAN PUSTAKa}

\section{A. Kualitas Air}

Kualitas air adalah kondisi kualitas air yang diukur dan diujikan berdasarkan parameter-parameter tertentu dan metode tertentu berdasarkan peraturan perundang-undanga yang berlaku (pasal 1 keputusan mentri negara lingkungan hidup nomor 115 tahun 2003) [3].

1. Air jernih

Berdasarkan keputusan Menteri kesehatan Republik Indonesia nomor 492/MENKES/PER/IV/2010, terdapat pengertian mengenai air bersih yaitu air yang 
Perancangan Dan Implementasi Alat Ukur Kualitas Air Menggunakan Metode Nefelometrik

digunakan untuk keperluan sehari-hari dan kualitasnya memenuhi persyaratan kesehatan air bersih sesuai dengan perundangan-undangan yang berlaku dan dapat diminum apabila dimasak [4].

2. Air Keruh

Air keruh merupakan salah satu ciri air yang tidak bersih dan tidak sehat. Departemen Kesehatan Indonesia menyatakan bahwa, air minum yang baik untuk dikomsumsi adalah air minum yang memiliki syarat-syarat antara lain tidak berasa, tidak berbau, tidak berwarna dan tidak mengandung logam berat [5].

\section{B. Metode Nefelometrik}

Metode Nefelometrik merupakan suatu metode pengukuran kekeruhan air dengan cara melewatkan sumber cahaya pada air sehingga intesitas cahaya yang dipantulkan oleh bahan-bahan penyebab kekeruhan air dapat diketahui. Semakin tinggi intensitas cahya yang dihamburkan maka tingkat kekeruhan semakin tinggi [6]. Rumus dari metode nefelometrik menurut Morais, Ines P.A, Ildiko V.T, Antonio O.S.S.R, 2013, dapat di jelaskan sebagai berikut [7] :

$$
\mathrm{I}=\mathrm{k} \text {. lo. c }
$$

$\mathrm{I}=$ intensitas cahaya

$\mathrm{K}=$ kostanta (tergantung pada ukuran beberapa factor seperti ukuran dan bentuk hamburan partikel dan panjang gelombang dari sumber radiasi ).

$\mathrm{Io}=$ intensitas sumber radiasi yang ditrasmisikan oleh blanko.

$\mathrm{C}=$ konsentrasi $(\mathrm{w} / \mathrm{v})$.

Untuk mencari konsentrasi didapatkan rumus sebagai berikut :

$$
\mathrm{ml} \times \frac{\mathrm{g}}{1 \mathrm{ml}}
$$

\section{Metode Penelitian}

Blog diagram sistem ini akan membahas tentang sistem yang ada pada alat ukur kualitas air menggunakan metode nefelometrik, adapun blog diagram sistem dapat dilihat pada Gambar 1.

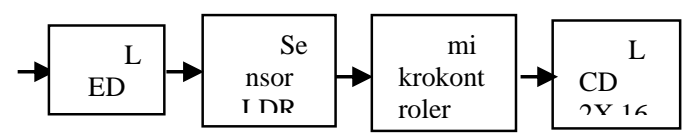

Gambar 1. Blok Diagram Sistem

Sensor kekeruhan air mengirimkan data kualitas Nephelometrik Turbidity Unit (NTU) lalu mikrokontroler mengolah data tersebut untuk selanjutnya dirangkai informasi yang akan di tampilkan ke LCD jika beberapa keadaan sesuai dengan kondisi kualitas air. Penjelasan blok diagram sistem sebagai berikut :

a. Air yang digunakan dalam pengujian alat ukur kualitas air menggunakan air jernih dan air kotor. Air jernih yang digunakan adalah air kemasan (cleo, asa, cheers, gris dan club) sedangkan air keruh atau tidak jernih menggunakan air (pertanian, perternakan, cucian baju, kopi dan teh).

b. Led digunakan sebagai sumber cahaya, cahaya yang digunakan berwarna putih. Sumber cahaya digunakan untuk membatu sensor LDR dalam penerima cahaya.

c. Sensor cahaya LDR yang mengirimkan sinyal ADC, kemudian akan diproses dan menghasilkan nilai berupa kualitas dengan satuan NTU. LED akan menjadi sumber cahaya untuk membantu LDR dalam mendeteksi kualitas air. LCD disini sebagai output informasi yang sudah diolah sistem LCD untuk menampilkan data

d. Mikrokontroler yang memakai arduino uno akan menerima inputan tersebut, proses selanjutnya adalah coding yang terpasang pada chip. Tidak hanya kualitas yang diterima oleh mikrokontroler, melainkan ketika sistem mikrokontroler mengirimkan informasi "jernih 8000 NTU" maka dari itu cara untuk mengakalinya ke LCD.

e. Pada pengujian alat kekeruhan ini menggunakan 10 jenis cairan dengan nilai $1 \mathrm{NTU}, 10 \mathrm{NTU}$, 25 NTU, 50 NTU, 100 NTU, 250 NTU, 500 NTU, dan 1000 NTU. Air tersebut akan di letakan pada wadah (gelas ukur) dan di letakan pada sensor LDR dengan sudut $90^{\circ}$.

f. Pengujian secara keseluruhan dilakukan dengan menggukur perubahan resistansi tegangan yang dihasilkan oleh sensor LDR dan LED terhadap 
intensitas cahaya yang masuk terhadap berbagai macam air yang tenang.

Perubahan resistansi dari sensor LDR ini dilanjutkan ke mikrokontroler Atmega 328. Karena sinyal keluar dari sistem sensor analog, maka dibutuhkan ADC untuk mengkonversi sinyal analog ke digital agar bisa terbaca oleh rangkaian mikrokontroler Atmega 328. Selanjutnya menjadi masukan pada program, dan diproses untuk di tampilkan ke LCD 2 X 16.

\section{A. Alat yang Digunakan}

\section{Liquid Cristal Display (LCD)}

LCD (Liquid Cristal Display) komponen elektronika yang berfungsi sebagai tampilan suatu data, baik karakter, huruf, atau pun grafik. Dipasaran tampilan LCD sudah tersedia dalam bentuk modul yaitu tampilan LCD beserta rangkaian pendukungnya termasuk ROM. LCD mempunyai pin data, control catu daya, dan pengaturan kontras tampilan. Gambar LCD terdapat pada gambar 2 [8].

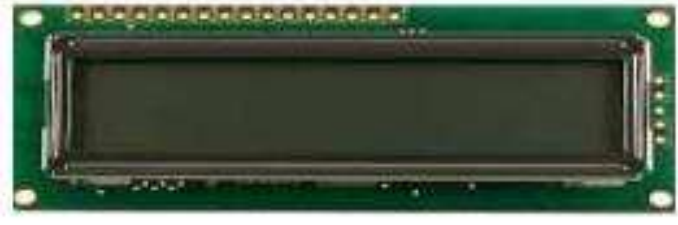

Gambar 2. Liquid Cristal Display (LCD)

\section{LDR (Light Dependent Resistors)}

Sensor cahaya LDR (Light Dependent Resistors) adalah salah satu jenis resistor yang dapat mengalami perubahan resistansinya apabila mengalami perubahan penerimaan cahaya. Besarnya nilai hambatan pada sensor cahaya LDR (Light Dependent Resistors) tergantung pada besar kecilnya cahaya yang diterima oleh LDR itu sendiri. LDR sering disebut dengan alat atau sensor yang berupa resistor yang peka terhadap cahaya. gambar LDR terdapat pada gambar 3 [8]

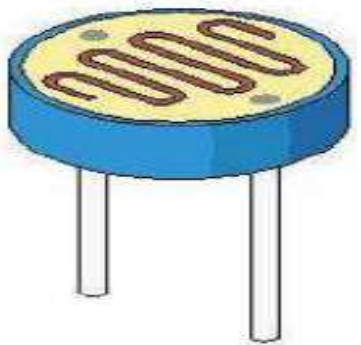

Gambar 3 LDR(Light Dependent Resistors

\section{Arduino UNO}

Arduino merupakan sebuah board mikrokontroler yang didasarkan pada ATmega328. Arduino uno memuat semua yang dibutuhkan untuk menunjang mikrokontoler, mudah menghubungkan ke sebuah komputer dengan sebuah kabel USB atau mensuplainya dengan sebuah adaptor AC ke DC atau menggunakan baterai untuk memulainya [9]

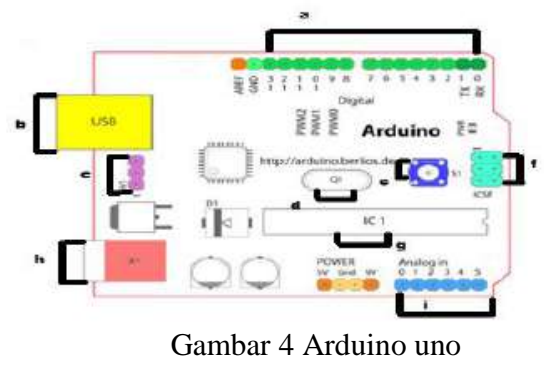

\section{Light Emitting Dioda (LED)}

LED adalah singkatan dari Light Emitting Dioda , merupakan komponen yang dapat mengeluarkan emisi cahaya. LED merupakan komponen yang dapat mengeluarkan emisi melepaskan energy berupa panas dan energy cahaya. Gambar LED terdapat pada gambar 2.4 [10].

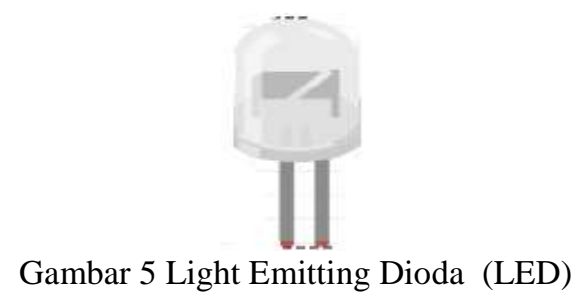

\section{B. Flow Chat Program}

Flow chat program digunakan untuk mengetahui cara kerja dari alat ukur kualitas air. 


\section{$\underline{\text { Perancangan Dan Implementasi Alat Ukur Kualitas Air Menggunakan Metode Nefelometrik }}$}

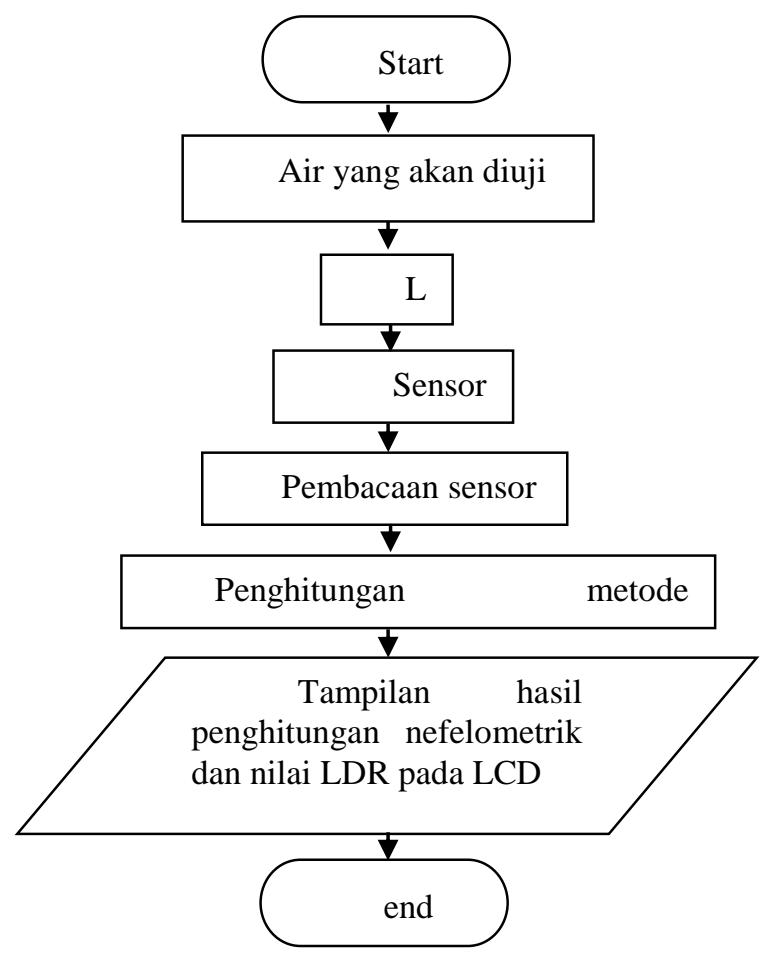

Gambar 6. Flow Chat Program

Dari flow chat program dapat dijelakan air yang akan diujikan adalah air kemasan, air olehan dan air limbah yang semuanya berjumlah 10 air. Led dipasang dengan teganga 5 volt, led yang telah dipasang akan member cahaya pada sensor LDR dan LDR akan mengeluarkan tegangan dari tingkat kualitas air yang akan diujikan. LCD di pasang dengan menancapkan kabel RS E D4 D5 D6 D7 pada LCD. sedangkan untuk angka $6,7,9,10,11,12$ di tancapkan pada arduino uno. Pin LDR di tancapkan pada A1 di arduino uno. Pembacaan sensor LDR dilakukan untuk mengetahui kondisi air dengan data tercemar 100 sampai 200, keruh 300 sampai 400, kurang jernih 500 sampai 600 dan jernih 700 sampai 1000. Metode nefelometrik digunakan untuk menghitung hasil intensitas cahaya, penghitungan tersebut dapat dilihat pada bab 2 hasil dari penghitungan metode nefelometrik dan nilai LDR dapat dilihat pada layar LCD 2 x 16 .

\section{Alur Metode Neflometrik}

Metode nefelometrik digunakan untuk mengukur kualitas pada sampel air dengan melewatkan cahaya melalui sampel dan mengukur jumlah cahaya yang dibelokan. Alur metode Nefelometrik terdapat pada Gambar 7.

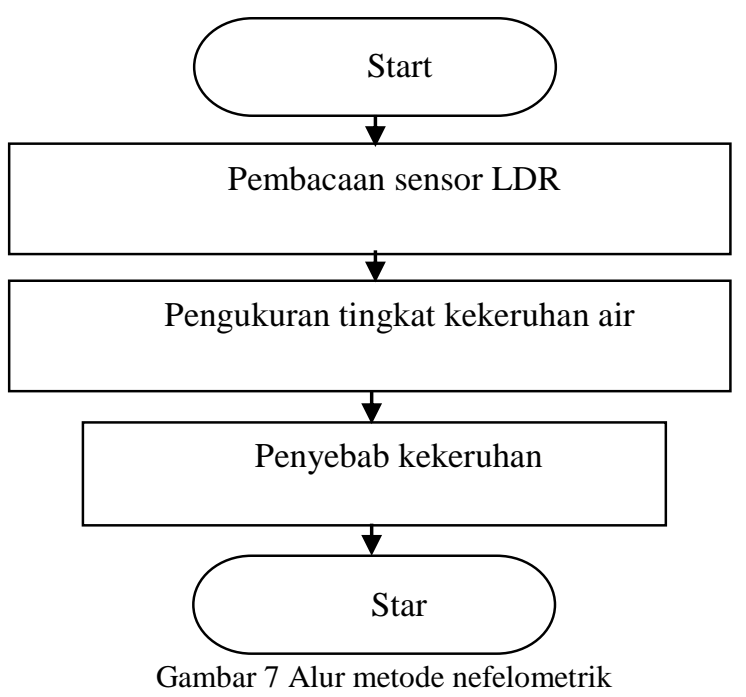

Dari alur metode nefelometrik LDR memiliki tugas membaca tingkat kualitas air yang akan dideteksi. Dari pembacaan sensor mendapatkan hasil dari air yang telah diujikan hasil tersebut berupa angka atau nilai tegangan, ADC dan NTU. Setelah nilai dari pengujian didapatkan maka diketahui penyebab kekeruhan air tersebut.

\section{Rancangan Alat Keseluruhan}

Perancangan alat ukur kekeruhan air ini terdiri dari inputan berupa air keruh yang akan dideteksi berupa air kemasan, air pertanian padi, air perikanan, LED sebagai cahaya dan sensor LDR sebagai sensor pendeteksi kekeruhan air. Mikrokontroler Atmega 328 sebagai pemroses dan output akan ditampilkan melalui LCD 2 x 16. Dapat dilihat pada gambar 8 . Rancangan alat yang akan peneliti gunakan pada alat ukur kualitas air terdapat pada gambar 2.5. Sepasang sensor intensitas cahaya yang terdiri dari LED sebagai sumber cahaya dan LDR berfungsi sebagai detektor cahaya.pembacaan sensor cahaya memanfaat perubahan nilai resistansi pada LDR. Dari perubahan nilai resistansi tersebut maka berpengaruh pada tegangan keluaran LDR. Arduino sebagai pusat. Hasil dari pengolahan data kemudian ditampilkan pada LCD Penampil LCD digunakan untuk mengetahui hasil dari tinggat kualitas air yang akan di uji menggunakan alat ukur kualitas air. 


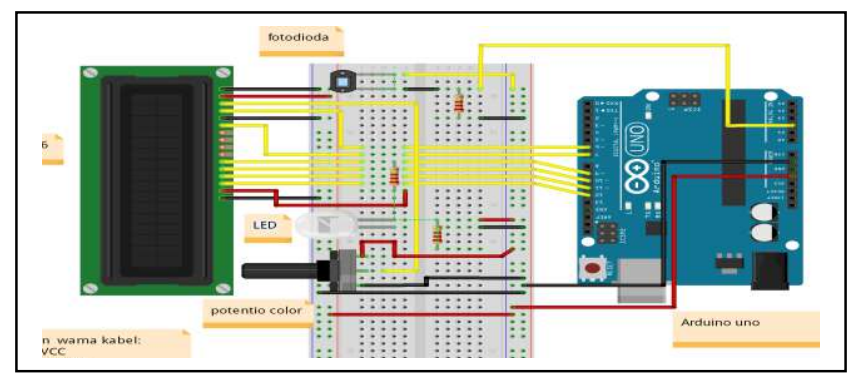

Gambar 8 Rancangan alat keseluruhan

\section{Hasil Dan Pembahasan}

\section{A. Alat - Alat Yang Digunakan}

Alat-alat yang digunakan untuk membuat alat ukur kualitas air menggunakan metode nefelometrik dapat dilihat pada gambar 9.

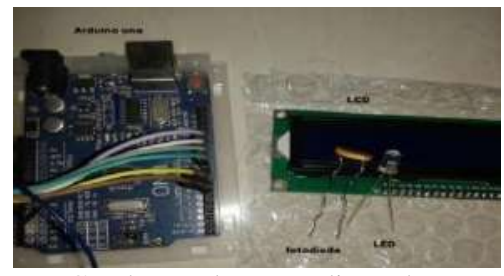

Gambar 9 alat yang digunakan

Pada gambar 3.1 terdapat alat arduino UNO, LED, LCD 2 X 16 dan LDR yang akan digunakan sebagai alat ukur kualitas air. Alat tersebut akan diuji cobakan satu persatu untuk mengetahui apakah alat tersebut dapat digunakan dalam mengetahui kulitas air jernih atau tidak. Pada gambar 9 menampilkan gambaran dari alat yang digunakan untuk mengukur kualitas air dan rancangan dari alat ukur kualitas air dapat dilihat pada gambar 10.

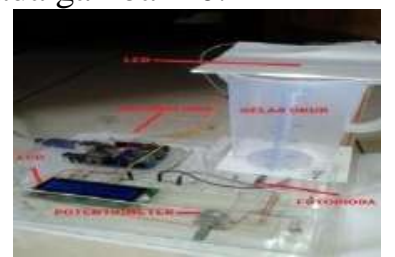

Gambar 10 Rancangan alat keseluruhan

Rancangan keseluruhan dari alat ukur kualitas air dapat dilihat pada gambar 10 Pada gambar terdapat gelas ukur, gelas ukur tersebut digunakan untuk menampung air jernih dan air kotor yang akan diuji mengguakan alat ukur kualitas air. Baterai atau daya digunakan untuk menjalan alat ukur kualitas air. Led digunakan untuk membatu sensor LDR dalam medeteksi kaulitas air, sensor LDR berfungsi untuk medeteksi air yang akan diuji cobakan. Led digunakan untuk menampilkan kondisi air, nilai NTU dan ADC. Potensio color digunakan untuk memper jelas tampilan pada layar LCD.

\section{B. Pengujian Alat Ukur Kualitas Air}

Untuk memastikan bahwa alat yang dibuat bisa digunakan dengan baik, maka dilakukan proses pengujian pada alat dan program yang meliputi :

\section{Pengujian Arduino UNO}

Pengujian arduino UNO ini berguna untuk memastikan apakah aduino UNO dapat digunakan untuk menjalankan sebuah program yang akan di gunakan dalam mengukur tingkat kualitas air. Didalam arduino terdapat pada led kecil yang terhubung ke pin no 13. LED ini dapat digunakan sebagai output untuk penanda jalannya sebuah program. Pengujian arduino terdapat pada gambar 11

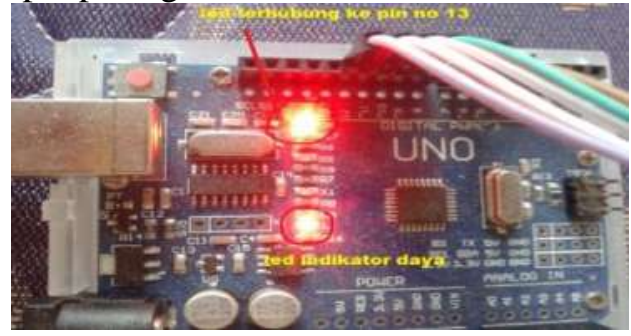

Gambar 11 pengujian arduino uno

2. Pengujian Sensor LDR

Pada pengujian LDR sangat penting sekali, karena untuk menyelesaikan alat ukur kualitas air yang akan dirancang butuh ketelitian yang akurat. Dan yang perlu diperhatikan adalah perubahan hambatan yang keluar dari LDR ketika mengenai cahaya dan ketika tidak mengenai cahaya. Pengujian sensor LDR ini untuk mengetahui apakah sensor dapat digunakan untuk mendeteksi cahaya yang akan dipasang pada alat ukur kualitas air. Jika sensor tersebut dapat mendeteksi cahaya maka sensor tersebut dapat digunakan pada alat ukur kualitas air. Dari gambar 12 dapat disimpulkan bahwa sensor LDR yang digunkan dalam pengujian dapat mendeteksi cahaya yang masuk. 


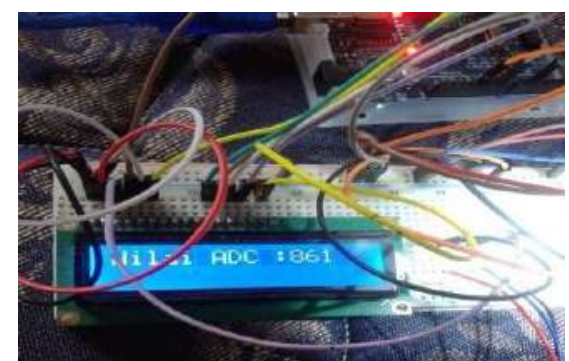

Gambar 12 Pengujian sensor LDR mengenai cahaya

3. Pengujian Keseluruhan Alat

Setelah semua alat yang dibutuhkan untuk membuat alat ukur kualitas air diujikan, alat tersebut dirakit satu-persatu menjadi sebuah alat ukur kualitas air. Gambar 13

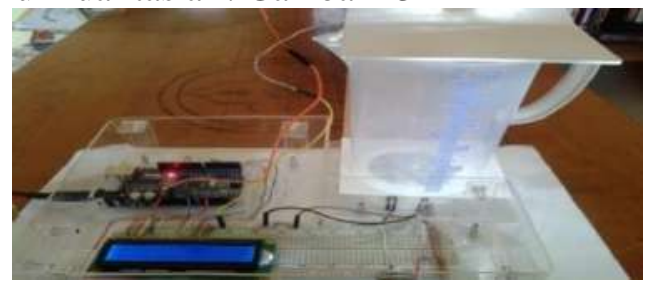

Gambar 13 pengujian keseluruhan alat

4. Pengujian Kualitas Air Minum Kemasan

Pengujian kualitas air kemasan yang terdeteksi oleh alat ukur kualitas air sebagai berikut:

1. Air asa dengan NTU 783,24, ADC 789 dan tegangan 1,131 .

2. Air cleo dengan NTU 764,4 , ADC 725,74 dan tegangan 0,798 .

3. Air gris dengan NTU 697,12 , ADC 661,42 dan tegangan 1,3808 .

4. Air club dengan NTU 671,14, ADC 743,22 dan tegangan 4,7894.

5. Air cheers dengan NTU 6561, ADC 631,68 dan tegangan 1,689 .

5. Pengujian Metode Nefelometrik

Hasil dari perhitungan menggunakan metode nefelometrik memperoleh nilai sebagai berikut :

1. Air cheers dengan hasil 70473888.

2. Air cleo dengan hasil 65236500 .

3. Air club dengan hasil 56880660.

4. Air gris dengan hasil 710010 .

5. Air asa dengan hasil 696069.
6. Pengujian Menggunakan Air Keruh

Pengujian kualitas air olahan atau air limbah yang terdeteksi oleh alat ukur kualitas air sebagai berikut:

1. Air teh dengan NTU 32752, ADC 402,16 dan tegangan 3,3698.

2. Air cucian baju NTU 433,32, ADC 437,3 dan tegangan 2,8502 .

3. Air perikanan NTU 162,44 , ADC 389,66 dan tegangan 3,3196.

4. Air sawah NTU 162,44, ADC 244,64 dan tegangan 4,1818.

5. Air kopi NTU 144,34, ADC 246,8 dan tegangan 4,2706 .

\subsection{Pengujian menggunakan metode neflometrik}

Hasil dari perhitungan menggunakan metode nefelometrik memperoleh nilai sebagai berikut :

1. Air teh dengan hasil 11315424,00.

2. Air kopi dengan hasil 1086240,00.

3. Air perikanan dengan hasil 53853012 .

4. Air cucian baju dengan hasil 568620 .

5. Air sawah dengan hasil 194964.

\section{KESIMPULAN}

Setelah dilakukan penelitian dengan menggunakan alat ukur kualitas air dapat disimpulkan sebagai berikut:

a. Penggunaan alat ukur kualitas air memiliki hasil yang tertinggi adalah Air kemasa asa dengan NTU 783,24, ADC 789 dan tegangan 1,131. Air limbah atau olahan teh dengan NTU 32752, ADC 402,16 dan tegangan 3,3698.

b. Hasil tertinggi dari penghitungan menggunakan metode nefelometrik adalah Air cheers dengan hasil 70473888 dan Air teh dengan hasil 11315424,00. 
Dari perancangan alat ukur kualitas air ini diharapkan dapat dikembangkan tidak adanya nilai tegangan secara otomatis pada alat ukur kualitas air dan penghitungan menggunakan metode nefelometrik yang terdapat pada program memiliki perbedan dengan hasil dari penghitungan menggunakann kalkulator.

\section{DAFTAR PUStaka}

[1] Pamularsih C, Choanji D, Widiasa IN, 2013, Penyisihan Kekeruhan Pada System Pengolahan Air Sungai Tembalang Dengan Teknologi Rapd Sand Filter,jurnal teknologi kimia dan industry vol.2,no.4, halaman 48-54, Semarang.

[2] Suryadi, 2013, Sistem Kendali Dan Monitoring Tingkat Kekeruhan Air Pada Bak Filtrasi Sebagai Bahan Baku Air Bersih.

[3] Keputusan Mentri Negara Lingkungan Hidup nomor 115 tahun 2003.

[4] Peraturan Metri Kesehatan RI NO 492/MENKES/PER/IV/2010.

[5] Yusfi M, Wildia, Hedlyni, 2011, Pemanfaatan sensor fototransistor dan LED inframerah dalam pendeteksi kekeruhan air berbasis mikrokontroler AT89S51,jurnal ilmu fisika (JIF), vol 3 no 2.

[6] Rasyid R, Wildian, Hendrizon Y, 2013, Uji Sensitivitas Sudut Hamburan Kekeruhan Air Bersi Dari Rancang Bangun Alat Ukur Nephelometer, prosiding seminar FMIP Universitas Lampung.

[7] Morais, Ines P.A, Ildiko V.T, and Antonio O.S.S.R, 2012, Turbidimetric and Nephelometric Flow Analysis: Concepts and Applications, Universidade Cato Iica Portuguesa, Portugal.

[8] Purwanto A, Sulhan M, 2015, Perancangan Alat Pendeteksi Tingkat Kekeruhan Air Pada Kamar Mandi Berbasis Mikrokontroler Atmega 8535. Malang.

[9] Ichwan M, Husada MG, Rasyid MIA, 2013 Pembangunan Prototipe Sistem Pengendalian Peralatan Listrik Pada PlatformArduino.

[10] Agung EF, Farhan M, Rachmansyah, Widiyanto EP, 2013, Sistem Deteksi Asap Rokok Pada Ruangan Bebas Asap Roko Dengan Keluaran Suara, 
Perancangan Dan Implementasi Alat Ukur Kualitas Air Menggunakan Metode Nefelometrik 